\section{ЛІТЕРАТУРА:}

1. Александров А. В. Анализ механизма модуляции межклеточных молекул адгезии ICAМ / А. В. Александров, А. М. Джексон, А. Г. Румянцев // Иммунология. 1997. - № 1. - C. 4-13.

2. Васильева Г. И. Кооперативное взаимодействие моно- и полинуклеарных фагоцитов, опосредованное моно- и нейтрофилокинами / Г. И. Васильева, И. А. Иванова, С. Ю. Тюкавкина // Иммунология. 2000. - № 5. - C. 11-17.

3. Козлов И.Г. Рецепторы контактного взаимодействия / И. Г. Козлов, Н. К. Горлина, А. Н. Чередеев // Иммунология. - 1995. - № 4. - С. 14-24.

4. Кочемасова Т. В. Состояние эндотелия и адгезия лейкоцитов при сахарном диабете / Т. В. Кочемасова // Сахарный диабет. - 2000. - № 3. - С. 17-21.

5. Ларина И. В. Клиническое и прогностическое значение различных иммунологических показателей при рассеянном склерозе / И. В. Ларина [и др. ] / Мат. Х конф. «Нейроиммунология». - 2003. - Российский биомедицинский журнал. - С. 20-21.

6. Мельников О. Ф. Влияние иммуномодуляторов in vitro на экспрессию CD-антигенов на лимфоцитах периферической крови больных хроническим тонзиллитом / О. Ф. Мельников, В. В. Олейник, М.Б.Самбур[идр.]//Імунологіятаалергологія.-2004.№ 3. - С. 7-10.

7. Насонов Е. Л. Растворимые молекулы адгезии (Р-селектин, ICAM-1 и ICAM-3) при ревматоидном артрите / Насонов Е. Л., Самсонов М. Ю., Тилз Г. П. [и др. ] // Тер. архив. - 1999. - № 5. - С. 17-20.

8. Серебренникова С. Н., Семинский И. Ж. Влияние цитокинов на клетки очага воспаления / С. Н. Сере бренникова, И. Ж. Семинский // «Проблемы и перспективы современной науки». - 2009. - Том 2, вып. 1. - С. 21-24.

9. Старикова Э. А. Изменения поверхностного фенотипа эндотелиальных клеток под влиянием провоспа- лительных и противовоспалительных цитокинов// Медицинская иммунология / Э. А. Старикова [и др. ] - 2003. - Том 5, № 1-2. - с. 39-48.

10. Черний В. И. Нарушения иммунитета при критических состояниях. Особенности диагностики / В. И. Черний, А. Н. Нестеренко // Внутренняя медицина». - 2007. - № 3. - С. 14-19.

11. George Cr. From Fahrenheit to cytokines : fever, inflammation and the kidney / Cr. George // J. Nephrol. 2006. - Suppl 10. - P. 88-97.

12. Inamura $H$. Expression of adhesion molecules on cordblood-derived, cultured human mast cells and effect of dexamethasone on intercellular adhesion molecule-1 expression on the mast cells by phorbol myristate acetate / H. Inamura [et al. ] // Allergy. - 2001. - Vol. 56. P. 672-678.

13. Malik I. S. Soluble adhesion molecules in ishaemic heart disease / I. S. Malik, D. O. Hascard // Europ. Heart J. 1999. - Vol. 20, N 14. - P. 990-991.

14. Sigal $A$. The LFA-1 integrin supports rolling adhesion on ICAM-1 under physiological shear flow in a permissive cellular environment / A. Sigal [et al. ] // J. Immunology. - 2000. - Vol. 165. - P. 442-452.

15. Tsujimoto Y., Shimizu S. Bcl-2 Family : life-or-death switch / Y. Tsujimoto, S. Shimizu // FEBS. - 2000. Vol. 466., N 1. - P. 6-10.

16. Uchio E. Serum levels of soluble intercellular adhesion molecule-1, vascular cell adhesion molecule-1, and interleukin-2 receptor in patients with vernal keratoconjunctiyitis / E. Uchio, S. Ono, Z. Ikezawa // Allergy. 1999. - Vol. 54. - P.135-141.

17. $W u M$. Expression of ICAM-1 in patients with endomethriosis / M. Wu // Fertility and Sterility. - 1998. Vol. 70, N 6. - P. 1139-1142.

Надійшла до редакції 19.01.2015

Прийнята до друку 26.01.2015

(c) Топчій I.І., Семенових П.С., Гальчінська В.Ю., Єфімова Н.В., 2015

УДК:616.61:616.379-008.64-092

І.І. ТОПЧІЙ, П.С. СЕМЕНОВИХ, В.Ю. ГАЛЬЧІНСЬКА, Н.В. ЕФІМОВА ПОРУШЕННЯ ВМІСТУ ВІСФАТИНУ В ПЕРИФЕРИЧНІЙ КРОВІ ХВОРИХ НА ДІАБЕТИЧНУ НЕФРОПАТІЮ

\author{
I.I.TOPCHII, P.S. SEMENOVYKH, V.YU. GALCHINSKAYA, N.V. YEFIMOVA
}

\title{
VISFATIN LEVEL DISTURBANCES IN PERIPHERAL BLOOD OF PATIENTS
} WITH DIABETIC NEPHROPATHY

ДУ «Національний інститут терапії ім. Л.Т.Малої НАМН України», м. Харків SI «National Institute of Therapy named after L. Malaya of NAMS of Ukraine», Kharkov

Топчій Іван Іванович

itopchiy@yandex.ua
Ключові слова: діабетична нефропатія, вісфатин, індекс маси тіла.

Key words: diabetic nephropathy, visfatin, body mass index. 
Резюме. Введение. Последние исследования доказали, что висфатин участвует в патогенезе сосудистых осложнений диабета, в частности диабетической нефропатии (ДН). Цель исследования - определение уровня висфатина в периферической крови больных сахарным диабетом (СД) 2-го типа в зависимости от нарушения функции почек и индекса массы тела (ИМТ).

Материалы и методы. Обследовано 94 больных СД 2-го типа с разными стадиями ДН и 10 практически здоровых лии (контрольная группа). Концентрацию висфатина в плазме крови определяли методом иммуноферментного анализа.

Результаты. У больных ДН имеет место существенное повышение уровня висфатина в плазме крови уже на начальных стадиях болезни. Прогрессирование заболевания сопровождается более выраженным ростом концентрации висфатина. У больных с повышенным и высоким ИМТ отмечается значительное повышение уровня висфатина в плазме крови по сравнению с пациентами с нормальным ИМТ. Установлено прямую корреляционную связь концентрации висфатина с уровнями альбумина мочи и креатинина крови и обратной корреляционная связь со скоростью клубочковой фильтрации.

Выводы: Выявленные связи свидетельствуют, что уровень висфатина отображсает функциональное состояние почек и может быть использован как дополнение к традиционным методам обследования больных.

Summary. Introduction. Recent studies suggest that visfatin participates in pathogenesis of vascular diabetic complications, in particular diabetic nephropathy $(D N)$. The aim of the present research - definition of visfatin level in peripheral blood of type 2 diabetic patients taking to account renal function disturbances and body mass index (BMI).

Materials and methods. 94 type 2 diabetic patients with different stages of $D N$ and 10 healthy subjects (control group) were observed. Visfatin concentration in blood plasma was determined using immunoassay kit.

Results. An essential increase of visfatin level in blood plasma took place already in initial stages of the DN. Progressing of the disease was accompanied by more expressed growth of visfatin concentration. In patients with high BMI substantial increase of visfatin level when compared with those with normal IMT was determined. We established strong correlations between visfatin concentrations, urinary albumin levels and blood creatinine concentrations and negative correlations with glomerular filtration rate.

Conclusions: Our findings testify that visfatin level displays a functional kidney state and may be used as addition to traditional methods of patients examination.

ВСТУП. Рання діагностика та лікування ураження нирок мають принципове значення для покращення прогнозу у хворих на ДН. У зв'язку з цим продовжується пошук нових діагностичних та прогностичних маркерів, що відображали б найбільш ранні стадії даного ускладнення цукрового діабету. В останні роки активно досліджують адгезивні, ангіогенні, тромбогенні фактори, а також медіатори запалення, до яких, зокрема, відносять вісфатин. Вісфатин (колонієстимулюючий фактор пре клітин) - адипокін, що продукується вісцеральними адипоцитами, клітинами печінки, кісткового мозку та м'язів [10]. Донедавна вісфатин розглядався як фактор, що асоціюється з метаболічним синдромом, ожирінням та інсулінорезистентністю [2].

В експериментальних роботах показано, що вісфатин суттєво й дозозалежно підвищує експресію генів і продукцію ростових факторів та металопротеїназ [9]. Вісфатин відіграє значну роль і як цитокін, що продукується екстрацелюлярно у відповідь на запальні стимули (LPS, TNF $\alpha$, IL-1, IL-6), та як модулятор реакцій імунітету при наявності системного запалення [10]. Дослідження in vitro показали, що розчинний вісфатин людини активує моноцити, індукує секрецію прозапальних цитокінів i, у той же час, підсилює поверхневу експресію таких молекул-маркерів запалення, як CD54 та CD40 [8]. W-J. Lee i співавтори досліджували вплив вісфатину на експресію молекул адгезії й цитокінів в культурі ендотеліальних клітин. Вісфатин значно підвищував експресію генів IL-6, IL-8, ICAM-1,
VCAM-1 і Е-селектина. Преінкубація з вісфатином стимулювала адгезію моноцитів [14]. Враховуючи такий потужний вплив вісфатину на основні ланки запальних процесів, безумовно, слід очікувати на участь даного медіатору в формуванні запальних, склеротичних та фібротичних змін в нирковій тканині при ЦД. Проте, дослідження ролі вісфатину в формуванні ниркових уражень у хворих з коморбідною патологією, зокрема при поєднанні діабету та ожиріння, неоднорідні та суперечливі.

В зв'язку з вищевказаним в даному фрагменті науково-дослідної роботи ми вивчали вміст вісфатину в периферичній крові хворих на ЦД 2-го типу з урахуванням IMT та порушення функції нирок.

МАТЕРІАЛИ ТА МЕТОДИ. Дослідження проводилося у клініці ДУ «Національній інститут терапії ім. Л.Т.Малої НАМН України». Лабораторні дослідження виконані на базі лабораторії клінічної і експериментальної морфології ДУ «Національній інститут терапії ім.. Л.Т. Малої НАМН України».

Під спостереженням знаходилося 94 хворих на ЦД 2-го типу з різними стадіями ДН. Хворі перебували на обстеженні та лікуванні у відділі нефрології. Серед обстежених було 45 чоловіків і 49 жінок, середній вік пацієнтів - $(53,9 \pm 1,8)$ роки.

Діагноз і стадію ДН було встановлено відповідно до класифікації Mogensen C.Е. (1983 р.) на підставі загальноклінічних методів обстеження (клінічні аналізи крові і сечі, глікемічний профіль, визначення мікроальбумінурії, протеїнурії, визначення рівня креатиніну і сечовини в крові і сечі, 
ультразвукове дослідження паренхіми нирок, вимірювання артеріального тиску).

Індекс маси тіла (IMT) обчислювали за формулою:

$$
I=\frac{m}{h^{2}},
$$

де: $\mathrm{m}$ - маса тіла в кілограмах, $\mathrm{h}$ - зріст в метрах.

Хворі були розподілені на групи в залежності від ступеня ураження нирок. Так, в першу групу включили 58 осіб з початковими доклінічними стадіями захворювання - ДН I-III стадій за Mogensen. Друга група складалася 336 хворих з вираженими клінічними проявами ураження нирок: протеїнурією та порушенням азотовидільної функції - ДН IV-V стадій.

За IMT хворі були розподілені наступним чином: 32 обстежених мали нормальні значення IMT i 62 особи - підвищений IMT.

Контрольна група складалась 310 практично здорових осіб.

3 дослідження виключали осіб з декомпенсацією ЦД, наявністю первинної патології нирок (сечокам'яна хвороба, інфекції сечовивідних шляхів, уроджені аномалії сечовивідних шляхів і нирок), важкими захворюваннями печінки, злоякісними захворюваннями, захворюваннями системи крові.

Дослідження мікроальбумінурії проводили 3 використанням тест-смужок „Мікроальбуфан” (Pliva-Lachema Diagnostika, Чехія). Визначення протеїнурії проводили методом Робертса-Стольнікова.

Функцію нирок оцінювали 3 урахуванням швидкості клубочкової фільтрації, яку обчислювали за формулою MDRD.

Концентрацію вісфатину визначали методом імуноферментного аналізу з використанням тестсистеми виробництва «RayBiotech, Inc.» (США). В якості індикаторного ферменту застосовували пероксидазу хрону. Діапазон концентрацій, що вимірюються становив від 0,1 до 1000 нг/мл.

Статистичну обробку проводили за допомогою комп'ютерних програм “SPSS 13”, “Microsoft Excel 2000”. Статистичні гіпотези про різницю середніх перевіряли, використовуючи непараметричний критерій Манна-Уітні. Вірогідними вважали розходження при $\mathbf{p}<0,05$. Дані представлені як середнє значень, шо вимірювали у двох паралельних пробах (M), і стандартна помилка (m).

Для оцінки міри залежності між вибірками також використовували непараметричні методи статистики (коефіцієнт рангової кореляції Спірмену).

РЕЗУЛЬТАТИ ДОСЛІДЖЕННЯ ТА ЇХ ОБГОВОРЕННЯ. Згідно отриманих даних, у хворих на ДН з нормальною вагою рівень вісфатину перевищував контрольні значення у1,7 рази та становив $(37,2 \pm 3,5)$ нг/мл (рис. 1).

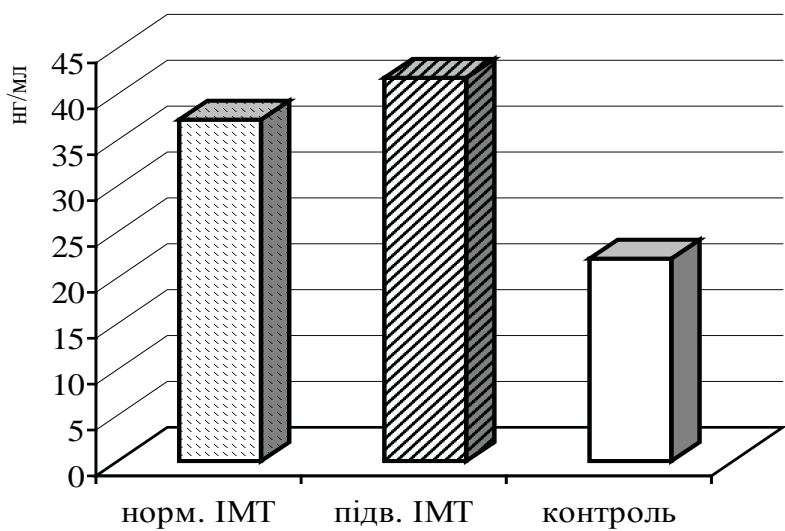

Примітка. * - вірогідно у порівнянні 3 контролем (здорові донори), $\mathrm{p}<0,05$.

Рис. 1. Рівні вісфатину в плазмі крові хворих з нормальним та підвищеним IMT.

У пацієнтів зі збільшеною масою тіла було виявлено більш виразне зростання показника - майже в 2 рази в порівнянні зі здоровими донорами. В цій групі рівень вісфатину в плазмі крові становив $(41,8 \pm 4,6)$ нг/мл.

Слід зазначити, жирова тканина більше не розглядається тільки як енергетичне депо, іiі роль виходить далеко за рамки енергетичного обміну. Нові дані представляють іiі як ендокринний і паракринний орган, здатний впливати на інші органи й системи. Ці властивості жирової тканини відрізняються залежно від морфології самих адипоцитів та їх локалізації. Вісцеральний жир (мезентеріальні адипоцити) значно активніший в ендокринологічному плані, ніж підшкірний. При надлишковій масі тіла відбувається не тільки проліферація й гіпертрофія адипоцитів, але й їх інфільтрація макрофагами з наступним розвитком запальних реакцій, внаслідок чого змінюється метаболічна активність жирової тканини [4]. Саме тому ряд вчених вважають патологічне ожиріння хронічним системним запальним процесом. Зокрема, L.M. Berstein звернув увагу на здатність компонентів жирової тканини бути мішенню для відповідних аутоантитіл [1] і розглядав це як доказ продукції гормонів і гормоноподібних субстанцій адипоцитами та можливості імунологічного регуляторного й терапевтичного впливу на функції жирової тканини.

Крім того, у сучасних публікаціях більшість дослідників характеризують абдомінальне ожиріння як незалежний фактор розвитку та прогресування хронічної хвороби нирок та зниження ШКФ. Результати клінічних та фундаментальних досліджень вказують, що гіпертонія, гіперглікемія та дисліпідемія, які є обов'язковими складовими метаболічного синдрому, в значній мірі сприяють розвитку та прогресуванню ДН. Ймовірно системне запалення та надмірна продукція адипоцитокінів, зокрема вісфатину, є ключовими медіаторами даних процесів. 
При вивченні концентрації вісфатину у хворих в залежності від стадії ДН, нами були отримані наступні результати: рівень останнього в плазмі крові суттєво підвищується вже на початкових етапах захворювання (рис. 2).

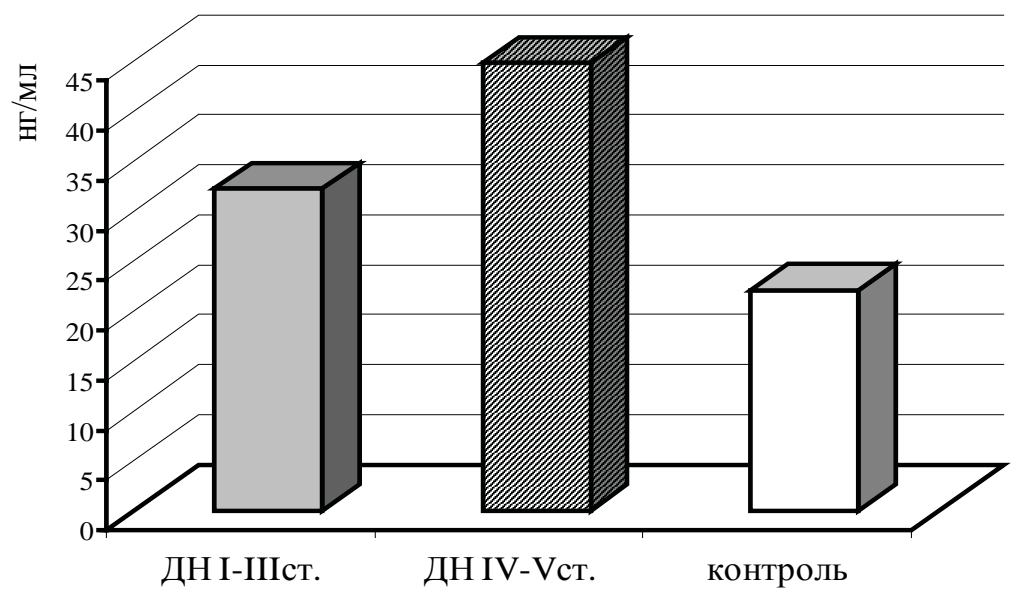

Примітка. * - вірогідно у порівнянні з контролем (здорові донори), $\mathrm{p}<0,05$.

Рис. 2. Рівні вісфатину у плазмі крові хворих та здорових донорів.

Так у пацієнтів $з$ доклінічними стадіями ДН (I-III ст. за класифікацією Mogensen) рівень вісфатину в крові становив $(32,4 \pm 3,8)$ нг/мл, контроль - $(22,5 \pm 1,9)$ нг/мл. Подальший розвиток захворювання супроводжувався більш значним зростанням показника у хворих з вираженими клінічними проявами ураження нирок - протеїнурією та нирковою недостатністю. Зокрема, в групі обстежених з ДН IV-V стадій концентрація вісфатину в плазмі крові становила $(44,9 \pm 5,2)$ нг/мл.

Таке суттєве збільшення вісфатину в залежності від стадії ДН свідчить про те, що порушення вмісту останнього при ЦД 2-го типу певною мірою пов'язане з ураженням нирок.

В наших попередніх дослідженнях та в роботах інших науковців була встановлена важлива роль інгібітору активатора плазміногена 1 типу (PAI-1) як найбільш значимого молекулярного медіатора фіброзу, який сприяє ремоделюванню туболоінтерстиція при нирковій патології. Показано, що в той час, як рівень PAI-1 практично не визначається в нормальних нирках, PHK PAI-1 або сам білок можуть суттєво підвищуватися при хворобах нирок, асоційованих з фіброзом [5]. Крім того, на даний час не викликає сумніву принципова роль моноцитарного хемоатрактантного протеїну 1 типу (МХП1) як ключового медіатора запалення в формуванні діабетичного ураження нирок [11]. Підвищені рівні PAI-1 та МХП-1 відзначаються при інсулінорезистентних станах, асоційованих з ожирінням, гіпертензією і діабетом [4, 11]. Дослідження даних маркерів при патології нирок визначають їх ключову роль у реакціях запалення, фіброзу й прогресування ренальної дисфункції.

В нашій роботі було виявлено взаємозв'язок вісфатину з PAI-1 та МХП-1 при проведенні кореляційного аналізу (табл. 1). Зокрема, встановлено, що підвищення вмісту PAI-1 й МХП-1 в плаз- мі крові хворих на ДН асоціюється зі зростанням концентрації вісфатину. Такі кореляції дозволяють зв'язати його функцію з системним запаленням та фіброзом як елементами патогенезу ДН.

Таблиця 1

Взаємозв'язок рівня вісфатину з маркерами запалення і фіброзу та основними показниками функціонального стану нирок у хворих на ДН

\begin{tabular}{|l|c|c|}
\hline & $\begin{array}{c}\text { коефіщієнт } \\
\text { кореляції, } \mathbf{r}\end{array}$ & вірогідність, $\mathbf{p}$ \\
\hline РАІ-1, пг/мл & $+0,57$ & $<0,05$ \\
\hline МХП-1, нг/мл & $+0,68$ & $<0,02$ \\
\hline протеїнурія, г/л & $+0,63$ & $<0,05$ \\
\hline креатинін, мкмоль/л & $+0,70$ & $<0,01$ \\
\hline ШКФ, мл/хв./1,73м² & $-0,58$ & $<0,05$ \\
\hline
\end{tabular}

При вивченні взаємозв'язку вісфатину з найбільш важливими показниками функції нирок отримано наступні результати: виявлено достовірні асоціації між ступенем протеїнурії, креатиніном крові та рівнем вісфатину в плазмі хворих на ДН (див. табл. 1). Крім того, встановлено зворотній кореляційний зв'язок швидкості клубочкової фільтрації з концентрацією вісфатину. Високі показники кореляції свідчать, що рівень останнього в певній мірі відображає функціональний стан нирок та може бути використаний як доповнення до традиційних методів обстеження хворих.

Отримані нами результати узгоджуються з даними Yilmaz et al., які показали, що рівень вісфатину корелює зі ступенем альбумінурії у хворих на ЦД 2-го типу. Автори роботи припускають, що розвиток ендотеліальної дисфункції на ранніх стадіях 
ДН асоціюється саме з підвищеною концентрацією вісфатину в плазмі крові [15].

Bessa S. та співавтори в Египетському дослідженні (Egyptian study) виявили зв'язок вісфатину з прозапальними цитокінами, адгезивними молекулами та ендотеліальною дисфункцією у пацієнтів з XXН. На основі отриманих даних, автори роботи розцінюють вісфатин, як важливий біомаркер системного запалення та ендотеліальної дисфункції при захворюваннях нирок [3]. Разом 3 тим Mahmood N. Та співавтори вважають, що підвищені рівні вісфатину асоціюються зі зниженням ШКФ при XXН, але не залежать від запалення та інсулінорезистентності [7].

На особливу увагу заслуговує той факт, що високі рівні вісфатину виявляють у хворих, які знаходяться на лікуванні як перитонеальним діалізом, так і програмним гемодіалізом. Встановлено позитивну кореляцію рівнів даного медіатору з усіма стадіями хронічної хвороби нирок [12].

Ключова роль вісфатину в патогенезі судинних ускладнень ЦД доведена в дослідженнях на експериментальних тваринах. Зокрема, Kang Y.S. та співавтори вивчали особливості продукції вісфатину на генетичній моделі ЦД 2-го типу. Автори встановили, що клітини гломерул та тубулоінтерстицій щурів з генетично детермінованим діабетом експресують підвищені рівні даного медіатора у порівнянні з контролем. Ці зміни супроводжуються зростанням рівня останнього в плазмі крові [6].

Значний інтерес викликають дослідження вісфатину in vitro. На клітинних культурах показано, що високі рівні глюкози стимулюють секрецію вісфатину мезангіальними клітинами. Важливо, що й вісфатин при додаванні в культуральне середовище суттєво підвищує продукцію таких профібротичних молекул, як фактори росту, колаген та PAI-1, мезангіальними клітинами [13].

Доведено, що секреція вісфатину здійснюється не тільки адипоцитами, але й макрофагами жирової тканини. Відзначено дозозалежний вплив вісфатину на продукцію прозапальних цитокінів (IL6 , TNF- $\beta$ та ін.). Ця обставина, а також позитивна кореляція між вісфатином і С-реактивним білком, дозволяють зв'язати його функцію з системним запаленням як елементом патогенезу ниркових ускладнень у хворих на ЦД та ожиріння.

Таким чином, в прогресуванні патології нирок при ожирінні й діабеті має значення цілий комплекс метаболічних, судинних і гормональних порушень. Не викликає сумніву, що ушкодження структур нирок тісно пов'язане з впливом біологічно активних речовин, які продукуються адипоцитами та макрофагами жирової тканини. Ці порушення запускають цілий каскад запальних, проліферативних і гемодинамічних змін у нирках, кінцевим результатом якого $€$ розвиток гломерулосклерозу й тубулоінтерстиціального фіброзу.

Зміна рівнів медіаторів запалення та фіброзу $є$ важливою ланкою в патогенезі таких коморбід- них станів, як ожиріння та діабет. Отримані нами результати свідчать, що прозапальний адипокін вісфатин відіграє принципову роль в формуванні судинних ускладнень діабету, зокрема ДН.

Для установлення причинно-наслідкових зв'язків вісфатину 3 іншими патогенетичними факторами потрібні подальші дослідження в цьому напрямку, але вже зараз очевидно, що вісфатин має принципове значення в процесах патогенезу ДН, а підвищення його рівню сприяє прогресуванню захворювання. Блокада медіаторів запалення й фіброзу є важливим підходом у пошуку нових методів лікування ниркових ускладнень при ЦД та ожирінні.

\section{ВИСНОВКИ:}

1. У плазмі крові хворих на ДН виявлено суттеве підвищення рівня вісфатину у порівнянні з контролем вже на початкових стадіях хвороби. Прогресування захворювання супроводжується більш вираженим зростанням вмісту вісфатину.

2. У хворих з підвищеним та високим IMT відзначається суттєве збільшення вмісту вісфатину плазми крові у порівнянні 3 пацієнтами з нормальним IMT.

3. Встановлено прямий кореляційний зв язок концентрації вісфатину з рівнями альбуміну сечі й креатиніну крові та зворотній кореляційний зв'язок зі ШКФ. Виявлена залежність свідчить про можливість відображення функціонального стану нирок за рівнем вісфатину, який може бути використаний у якості діагностичного маркеру.

\section{ЛІТЕРАТУРА:}

1. Берштейн Л.М. Гормоны жировой ткани (адипоцитокины) / Берштейн Л.М. // Успехи геронтологии. - 2005. - №16. - С. 51-64.

2. Adeghate $E$. Visfatin: structure, function and relation to diabetes mellitus and other dysfunctions / Adeghate E. // Curr Med Chem. - 2008. - vol. 15. - P. 1851-1862.

3. Bessa S. S. Serum visfatin as a non-traditional biomarker of endothelial dysfunction in chronic kidney disease: an Egyptian study / S. S. Bessa, S. M. Hamdy, R. G. ElSheikh // Eur J Intern Med. - 2010. - vol. 21(6). P. 530-535.

4. Guzik T. J. Adipocytokines - novel link between inflammation and vascular function. / T. J. Guzik, D. Mangalat, R. J. Korbut // Physiol Pharmacol . - 2006. - vol. 57. P. 505-528

5. Huang Y. PAI-1 as a target in kidney disease. / Huang Y., Noble N.A. // Curr Drug Targets. 2007 - Vol. 8, № 9. - P.1007-1015.

6. Kang Y.S. Visfatin is upregulated in type-2 diabetic rats and targets renal cells / Y. S. Kang, H. K. Song, M. H. Lee // Kidney Int. - 2010. - vol.78. - P.170-181.

7. Mahmood N. Association of visfatin with chronic kidney disease in a cohort of patients with and without diabetes / N. Mahmood, A. M. Junejo, Q. Jamal // J Pak Med Assoc. - 2010. - vol. 60. - P. 922-926. 
8. Moschen A. R. Visfatin, an adipocytokine with proinflammatory and immunomodulating properties / A. R. Moschen, A. Kaser, B. Enrich // J Immunol. 2007. - vol. 178(3). - P. 1748-1758.

9. Nuclear factor-kappaB induction by visfatin in human vascular endothelial cells: its role in MMP-2/9 production and activation / R. Adya, B. K. Tan, J. Chen [et al] // Diabetes Care. - 2008. - vol. 31(4). - P.758-760.

10. Sonoli S. S. Visfatin--a review / S. S. Sonoli, S. Shivprasad, C. V. Prasad [et al] // Eur Rev Med Pharmacol Sci. 2011. - vol. 15(1). - P. 9-14.

11. Tesch G. H. MCP-1/CCL2: a new diagnostic marker and therapeutic target for progressive renal injury in diabetic nephropathy / Tesch G. H. // Am J Physiol Renal Physiol. - 2008. - Vol.294. - P.697-701

12. Visfatin and apelin, new adipocytokines, and their relation to endothelial function in patients with chronic renal failure / J. Malyszko, J. S. Malyszko, K. Pawlak [et al] // Adv Med Sci. - 2008. - vol. 53(1). - P. 32-36.

13. Visfatin: a new player in mesangial cell physiology and diabetic nephropathy / H. K. Song, M.H. Lee, B.K. Kim [et al] // Am J Physiol Renal Physiol. - 2008. vol. 295. - P. 1485-1494.

14. Visfatin-induced expression of inflammatory mediators in human endothelial cells through the NF-kappaB pathway / W. J Lee, C. S. Wu, H. Lin [et al] // Int J Obes (Lond). - 2009. - vol. 33(4). - P. 465-472.

15. Yilmaz M. I. Endothelial dysfunction in type-2 diabetics with early diabetic nephropathy is associated with low circulating adiponectin / M. I. Yilmaz, M. Saglam, A. R. Qureshi // Nephrol Dial Transplant. - 2008. vol.23. - P.1621-1627

Надійшла до редакції 24.06.2014

Прийнята до друку 12.12 .2014

\section{Н.О. ПЕРЦЕВА}

\section{УШКОДЖЕННЯ ФУНКЦІЇ НИРОК ТА ДИНАМІКА ДИСЛІПІДЕМІЇ У ХВОРИХ НА ЦУКРОВИЙ ДІАБЕТ 2 ТИПУ 3 НЕДОСТАТНЬОЮ КОМПЕНСАЦІЕЮ ГЛІКЕМІЇ ЗА УМОВ КОРЕКЦІЇ АРТЕРІАЛЬНОЇ ГІПЕРТОНІЇ БЛОКАТОРАМИ РЕЦЕПТОРІВ АНГІОТЕНЗИНУ ІІ}

\section{N.O. PERTSEVA \\ DAMAGE OF RENAL FUNCTION AND DYNAMICS OF DYSLIPIDEMIA IN PATIENTS WITH TYPE 2 DIABETES MELLITUS WITH INSUFFICIENT GLYCEMIC COMPENSATION UNDER CONDITION OF CORRECTION OF HYPERTENSION WITH ANGIOTENSIN II RECEPTOR ANTAGONISTS}

Д3 «Дніпропетровська медична академія МОЗ України»

Ключові слова: иукровий діабет 2 типу, недостатня компенсація, артеріальна гіпертензія, нефропатія, дисліпідемія, блокатори рецепторів ангіотензину II.

Key words: diabetes mellitus type 2, insufficient compensation, arterial hypertension, nephropathic and dyslipidemic disorders, angiotensin II receptor antagonists.

Резюме. Повреждение функции почек и динамика дислипидемии у больных сахарным диабетом 2 типа с недостаточной компенсацией гликемии в условиях коррекции артериальной гипертонии блокаторами рецепторов ангиотензина II

Введение. Требуют изучения вопросы, связанные с динамикой нефропатических и дислипидемических нарушений на фоне длительного лечения артериальной гипертензии при использовании антагонистов рецепторов ангиотензина II у больных сахарным диабетом 2 типа.

Материалы и методы. Проведено лечение и обследование 87 больных сахарным диабетом 2 типа с недостаточной компенсацией гликемии и артериальной гипертензией. Изучена динамика нефропатических и дислипидемических нарушений на протяжении 1 года лечения.

Результаты и их обсуждение. На фоне стандартного лечения артериальной гипертензии происходят регрессия микроальбуминурии у 32,3\% больных, а также нормализация концентраций холестерина липопротеидов низкой плотности и триглицеридов через 1 год лечения. Антигипертензивная терапия с применением блокаторов рецепторов ангиотензина II существенно превышает по своей эффективности стандартную лечебную тактику по влиянию на развитие дислипидемии.

Выводы. После 6 месяиев лечения на фоне нормализации нефропатических и дислипидемических нарушений использование блокаторов рецепторов ангиотензина II сопровождается регрессией микроальбуминурии у $54,7 \%$ больных.

Перцева Наталія Олегівна

E-mail: npertseva@dsma.dp.ua
Summary. Damage of renal function and dynamics of dyslipidemia in patients with type 2 diabetes mellitus with insufficient glycemic compensation under condition of correction of hypertension with angiotensin II receptor antagonists 